\title{
Immediate Autogenous Extracted Tooth as a Grafting Material For Fresh Socket Preservation: a Systematic Review.
}

\section{Diente autógeno de extracción inmediata como material de injerto para la conservación de alvéolos frescos: Una revisión sistemática.}

Zurab Khabadze. ${ }^{1}$

Oleg Mordanov. ${ }^{1}$

Marina Dashtieva. ${ }^{1}$

la Todua. ${ }^{1}$

Julia Generalova. ${ }^{1}$

Artemy Nedashkovsky. ${ }^{1}$

Meri Sheroziia. ${ }^{1}$

Saida Adbulkerimova. ${ }^{1}$

Yusup Bakaev. ${ }^{1}$

Affiliations:

${ }^{1}$ RUDN University, Moscow, Russia.

Corresponding author: Oleg Mordanov. Miklukho-Maklaya Street, 6. Moscow, Russiaz. Phone: (+7) 91233 31533. E-mail: mordanov19@gmail.com

Receipt :09/20/2020 Revised: 05/06/2021 Acceptance:06/30/2021

Cite as:

Khabadze Z, Mordanov O, Dashtieva M, Todua L, Generalova J, Nedashkovsky A, Sheroziia M, Adbulkerimova S \& Bakaev Y. Immediate Autogenous Extracted Tooth as a Grafting Material For Fresh Socket Preservation: a Systematic Review.

J Oral Res 2021; 10 (3):1-7.

Doi:10.17126/joralres.2021.027
Abstract: Objectives: To evaluate the use of extracted autogenous teeth for socket preservation after tooth extraction. Material and Methods: Cochrane, Scopus, and PubMed databases search was conducted to identify human clinical studies reporting the clinical, radiographic and/or histological outcomes of socket preservation techniques with autogenous extracted tooth Only studies published in English language in the last 10 years were included in the study. Results: In total, 82 articles were identified. Five articles were included in the review. They included 58 teeth that were prepared as a graft for socket preservation. The grafts derived from autogenous teeth were presented in three forms: particles, blocks and powder. The mean bone loss ranged from $0.28 \mathrm{~mm}$ to $0.41 \mathrm{~mm}$ in height and $0.15 \mathrm{~mm}$ in width. Conclusion: Immediate autogenous extracted tooth as a grafting material for fresh socket preservation is promising for future daily clinical practice. More clinical comparative studies are needed.

Keywords: bone transplantation; bone remodeling; systematic review; autografts; alveolar process; tooth extraction.

Resumen: Objetivo: Evaluar el uso de dientes extraídos autógenos para la preservación del alveolo tras la extracción dental.Material y Métodos: Se realizó una búsqueda en las bases de datos Cochrane, Scopus y PubMed para identificar estudios clínicos en humanos que informaban los resultados clínicos, radiográficos y / o histológicos de las técnicas de preservación de alveolos con dientes extraídos autógenos. Solo se incluyeron estudios publicados en inglés en los últimos 10 años. Resultados: En total se identificaron 82 artículos. Se incluyeron cinco artículos en la revisión. Incluyeron 58 dientes que se prepararon como injerto para la preservación del alveolo. Los injertos derivados de dientes autógenos se presentaron en tres formas: partículas, bloques y polvo. La pérdida ósea media osciló entre 0,28 mm y 0,41 mm de altura y 0,15 mm de ancho. Conclusión: El diente autógeno extraído de forma inmediata utilizado como material de injerto para la conservación del alveolo fresco es prometedor para la práctica clínica diaria futura. Se necesitan más estudios clínicos comparativos.

Palabra Clave: trasplante óseo; remodelación ósea; revisión sistemática; autoinjertos; proceso alveolar; extracción dental.gen. 


\section{INTRODUCTION.}

The bone and soft tissue alterations secondary to tooth extraction have a significant impact on the outcome of implant-supported restorations. ${ }^{1}$ Deficiency of the facial bone affects negatively on esthetics and is a critical causative factor for esthetic implant complications and failure. ${ }^{2}$ Systematic reviews assessing the changes in alveolar bone dimension after tooth extraction have reported $2.6 \mathrm{~mm}-4.6 \mathrm{~mm}$ width reductions and $0.4 \mathrm{~mm}-3.9 \mathrm{~mm}$ height reductions. ${ }^{3,4}$ Bone regeneration requires the migration of specific cells to the healing socket to proliferate and provide the biological substrate for the new tissue development.

Cell migration, proliferation and differentiation is regulated by a number of factors in coordination with extracellular signals, three-dimensional support and scaffolds and with the correct blood supply. ${ }^{5}$

Allografts, xenografts, and alloplastic bone grafts, mesenchymal stem cells and bioactive molecules, bioglass, and/or hydroxyapatite and autogenous extracted tooth are utilized either with resorbable or non-resorbable membrane for extraction socket preservation. ${ }^{3,6-12}$ A bone graft material must be bimodal, which, in the early stages of differentiation, allows osteoblasts to build bridges between grains of different sizes and integrate with other osteoblasts, supporting both proliferation and differentiation. ${ }^{14,17,18}$

Autogenous tooth biomaterial derived from human extracted teeth is a potential material for bone regeneration due to its chemical composition and the high quantity of material obtained from each tooth. ${ }^{14}$

It is well known that the structure and composition of dentin is similar to that of bone, consisting of collagen 20\%, hydroxyapatite $70 \%$, and body fluid $10 \%$ by weight. ${ }^{13}$ After scanning electron microscopyenergy dis-persive $\mathrm{X}$-ray evaluation, it appeared that calcium and phosphates were still present within the collagen components even after the particle cleaning procedures. ${ }^{14}$ Thus, the aim of the systematic review is to evaluate the use of extracted autogenous teeth for socket preservation chairside after tooth extraction.

\section{MATERIALS AND METHODS.}

\section{Protocol and registration}

This systematic literature review adheres to the PRISMA Statement. The review protocol was registe- red in an international prospective register of systematic reviews (PROSPERO ID CRD42020189487) in which the methodology and inclusion and exclusion criteria were specified and documented.

Eligibility criteria

Publications that met the following selection criteria were included:

1. Full-text articles in English, not older than 10 years.

2. In vivo human studies and clinical trials, comparative studies, cohort studies and case series studies;

3. Fresh socket augmentation with the immediately extracted and prepared tooth;

4. At least 6 months of follow-up after the extraction and following procedure.

Publications that were not related to the topic of the study, literature reviews, as well as articles that did not have sufficient and specific data for the analysis were excluded.

\section{Information sources}

The electronic databases used for the search were Cochrane, Scopus, and PubMed and supplemented by a manual search and a gray literature search. It was not necessary to contact the authors to access the articles. The search started on January, 21, 2020 and ended on April 15, 2020.

\section{Search and Selection of Studies}

A search in English with no time limit was performed by three independent people. The following search query was used: [autogeneous OR autogenic AND tooth socket OR tooth AND socket AND preservation OR conser-vation]. The studies were filtered and selected in several stages. Firstly, they were evaluated by titles. Secondly, individual documents at the first stage were additionally assessed by reading the abstracts and full-text articles. The difference in the choice was resolved through discussion among the readers.

\section{Data collection process}

The data from different studies were extracted from studies according to the interests of the current review.

\section{Data items}

Data from the included articles were extracted and filled in the table with the following information: 
author and year, sample size, socket location, tooth extraction reason, results and conclusions.

\section{Risk of bias}

The assessment of the risk of bias was undertaken during the data extraction process. For the included studies, it was conducted using the Cochrane Collaboration's ROBINS-I tool for assessing the risk of bias. ${ }^{15,16,29}$

Overall risk of bias was then assigned to each trial, according to Higgins et al. ${ }^{16}$ The levels of bias were classified as follows: low risk, if all the criteria were met; moderate risk, when only one criterion was missing; high risk, if two or more criteria were missing; and unclear risk, if there were very few details to make a judgement about a certain risk assessment.

\section{Synthesis of results}

Tables were constructed with columns as data items.

\section{Statistical analysis}

No meta-analysis could be performed due to the high heterogeneity among the studies and the low number of studies.

\section{RESULTS.}

\section{Study selection}

Article review, selection and data extraction were conducted as shown in the preferred reporting items for systematic reviews and meta-analyses (PRISMA) flow diagram (Figure 1).

A manual search and a gray literature search did not result in any applicable results. In total, 82 articles were identified. Of those, 11 were identified as potentially relevant articles by the screening of the article titles and abstracts.

Finally, these 11 publications were evaluated by full-text reading.

Figure 1. Flow diagram of the article selection process, according to PRIMA guidelines.
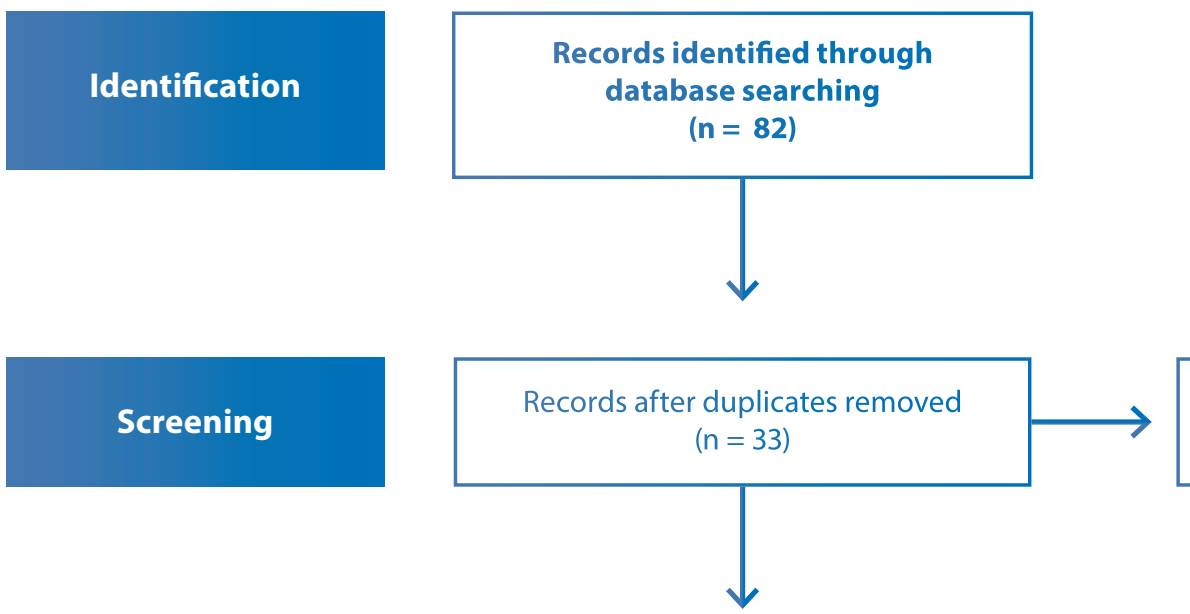

Not relevant titles and abstracts $(n=22)$
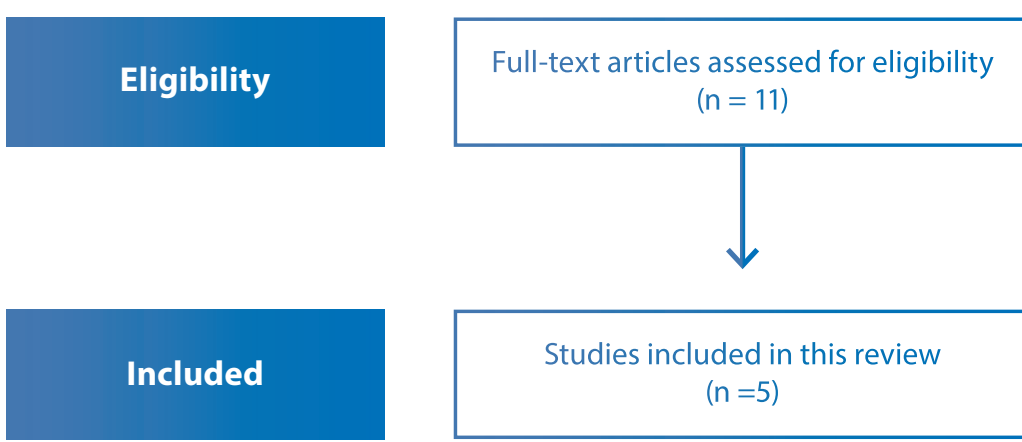

Full-text articles excluded, with reasons $(n=6)$

\section{Included}


Khabadze Z, Mordanov O, Dashtieva M, Todua L, Generalova J, Nedashkovsky A, Sheroziia M, Adbulkerimova S \& Bakaev Y. Immediate Autogenous Extracted Tooth as a Grafting Material For Fresh Socket Preservation: a Systematic Review. J Oral Res 2021; 10(3):xx-xxx. Doi:10.17126/joralres.2021.027

Table 1. Characteristics of studies. N/R - not reported.

\begin{tabular}{|c|c|c|c|c|c|}
\hline Authors & Year & $\begin{array}{c}\text { Number of } \\
\text { teeth extracted }\end{array}$ & $\begin{array}{c}\text { Socket location } \\
\text { reason }\end{array}$ & Tooth extraction & Results \\
\hline $\begin{array}{l}\text { Shejali } \\
\text { et al. }{ }^{19}\end{array}$ & 2020 & 13 & $\begin{array}{l}\text { Maxillary and } \\
\text { Mandibular single } \\
\text { rooted teeth }\end{array}$ & $\begin{array}{l}\text { Hopeless apical } \\
\text { periodontitis }\end{array}$ & $\begin{array}{l}\text { Clinical ridge width bet- } \\
\text { ween baseline and } 6 \text { mo- } \\
\text { nths postoperatively was } \\
\text { was } 5.9 \mathrm{~mm} \text { ( } p=0.001) \\
\text { The mean difference in } \\
\text { pre- operative and post- } \\
\text { operative alveolar ridge } \\
\text { width was } 5.8 \mathrm{~mm} \text {, sho- } \\
\text { wing a gain in the width } \\
\text { which was statistically } \\
\text { significant ( } p=0.001) \text {. }\end{array}$ \\
\hline
\end{tabular}

Kim

et al. ${ }^{20}$

Canto-Díaz 2019

et al. ${ }^{21}$

Minamizato 2018

et al. ${ }^{22}$

8

Impacted mesio-

dens (1); 11(1)-21(1); 35(1) $-36(1)-45(1)$;

$46(2)$

Joshi

2016

et al. $^{23}$
$-12(1)-21(2)$;

$3(1)-41(2)-42(2)$

Single-rooted teeth
22(1) - 31(2) - 32(3);
Apical periodontitis with the bone loss

Periodontal reason

$0.41 \mathrm{~mm}$ of bone loss, or $4.2 \%$ of the initial socket height and $0.15 \mathrm{~mm} \pm$ $0.08 \mathrm{~mm}$ width changes were observed
Apical periodontitis (3), root fracture (2), caries (2), and impacted mesiodens (1).

$N / R$
All implants had initial stability, with insertion torque $p$-values of 25 to $40 N^{*} \mathrm{~cm}$.

At second surgery 3 months after implant placement, the ISQ values ranged from 65 to 80 , with a mean $p$-value of 72.6 .

Sites grafted with extracted teeth consistently showed least reduction in ridge height, i.e., $0.28 \mathrm{~mm} \pm$ $0.13 \mathrm{~mm}$ which was significantly lower as compared to ungrafted sites $(p<0.05)$.
Immediate ridge augmentation using autogenous tooth root block graft can be an effective option in managing the periodontally hopeless extraction site indicated for implant placement

Autogenous fresh tooth presents good results for socket preservation using Auto-FDT with respect to implant installation and alveolar ridge maintenance.

The dimensional contraction of the post-extraction socket in the autologous dental material. The group was lower than the control group at 16 weeks after surgery, both vertically and horizontally.

The densitometric values (HU) in the autologous dental material. group remained stable and homogeneous between the three areas, being equal to the control group after 16 weeks, with the exception of the coronal area, which continued to show higher $p$-values

Extracted teeth prepared immediately after tooth extraction for bone augmentation, taking advantage of the relatively short preparation time with partial demidemineralization, have the potenpotential to become one of the options as a bone substitute in implant dentistry

The mean width change was $0.15 \mathrm{~mm} \pm 0.08 \mathrm{~mm}$. A mean width change for autogenous toothgrafted sites was significantly lesser when compared to $\beta$-TCP-grafted sites and ungrafted sites ( $p<$ $0.05)$. Extracted teeth showed more promising results as compared to $\beta$-TCP in achieving minimum volumetric alveolar bone loss when it is grafted immediately in a post-extraction socket.

This resorbable material allows most predictable, consistent, and reproducible bone regeneration. Derived from an extracted human tooth, it is the most easily available and cost effective material. 
After applying the inclusion and exclusion criteria, five articles fulfilled the predefined criteria and were, therefore, incorporated in the systematic review. They included three pilot studies, ${ }^{19,21,22}$ one case series $^{19}$ and one randomized, controlled, prospective, clinical pilot study. ${ }^{23}$ (Table 1).

Study characteristics and results of individual studies

Selected studies examine the efficacy and safety of an autogenous extracted tooth prepared onsite for fresh socket preservation. In total 58 teeth (30 of them were single rooted) were extracted and treated chairside for the fresh socket preservation and augmentation. Extraction reasons are indicated in Table 1.

The tooth indicated for extraction should have been free of soft tissue recession and the adjacent teeth should be periodontally healthy. Patients who were smokers, pregnant/lactating females, those on drugs affecting bone metabolism or radiation therapy and those not willing to participate were excluded from all studies. The grafts derived from autogenous teeth were presented in three forms: particles, ${ }^{20-22}$ blocks ${ }^{19,20}$ and powder. ${ }^{20,23}$ Generally removal of crowns or fillings of any kind (composites resins or amalgams), decay, or discoloured dentine, pulp (if presented), periodontal ligament and/or dental plaque were provided.

Shejali et al., ${ }^{19}$ trimmed the extracted tooth according to the measured defect site to adapt very closely over the recipient bone. After adequate trimming, the tooth root block was immersed in dentin cleansing solution (KometaBio, New Jersey, USA) for 10 minutes followed by the buffer saline solution (Dulbecco's Phosphate) for 2-3minutes to obtain a graft free of all the organic debris, resulting in a bacteria-free sterile graft.

The auto tooth grafts were stabilized with 1 or 2 titanium mini screws of $1.2 \mathrm{~mm}$ diameter and enclosed with resorbable collagen membrane. There is no specific information about Kim's et al., ${ }^{20}$ graft preparation.

Canto-Díaz et al., ${ }^{21}$ crushed dentine fragments in a crushing chamber capable of grinding the roots into particles of 300 and 1200 microns. The particles were ground for 3 separated using vibration for 20 seconds. Any particles smaller than 300 microns were discarded. Grafted sockets were sealed with a $15 \mathrm{~mm}$ $\times 20 \mathrm{~mm}$ collagen membrane. Minamizato et al.,22 crushed teeth with ice cubes in a ceramic cup using a specific machine with a high-speed rotation ceramic blade. Sockets were augmented with platelet-rich plasma (PRP).

Joshi et al., ${ }^{23}$ powdered teeth using a conventional grinder having motor rating $1500 \mathrm{~W}$ and speed of 700 rpm. The crushed granules were passed through two autoclaved stainless steel sieves in a sequential manner to obtain graft with particle size measuring between $300 \mu \mathrm{m}$ and $500 \mu \mathrm{m}$. All their grafted sites were covered with a membrane.

Clinical, radiographic and histological assessment

All included articles except of Kim et al., ${ }^{20}$ and Minamizato et al., ${ }^{22}$ provided clinical and radiographic measurements right after surgery and in 7 days $^{23}$ (only clinical assessment), 8 weeks, ${ }^{21} 16$ weeks ${ }^{21,23}$ and 6 mon-ths follow-up periods. ${ }^{19}$ Radiographic measurements were provided with cone beam computed tomography (CBCT). (Table 1)

Minamizato et al.,22 additionally measured initial stability and indicated insertion torque $p$-values of 25 to $40 \mathrm{~N} \mathrm{~cm}$ and ISQ values ranged from 65 to 80 with a mean value of 72.6 in 3 months after implant placement. A bone biopsy sample was collected using a $2.0 \mathrm{~mm}-3.0 \mathrm{~mm}$ trephine bur at 3 to 6 months postoperative from the transplanted sites of the patients who under-went socket preservation. In all articles histological analysis obtained from the bone core, demonstrated new bone formation along with complete organization. None of the sections demonstrated any remaining tooth graft particles.

Risk of Bias within Studies and Across Studies

Summarizing the risk of bias for each study, most of the studies were classified as an unclear risk. A number of studies were considered as having a low risk of bias.

There were several limitations present in the current review, including studies written in English only, which could introduce a publication bias.

There were various degrees of heterogeneity in each study design, materials and methods and treatment provided among the studies. 


\section{DISCUSSION.}

The current systematic review has included a number of articles analyzing the use of extracted teeth as a simultaneous preservation material for fresh sockets. The advantages of using a tooth as a graft are multiple. As it is an autograft, there is no possibility of graft rejection or cross infection. The graft is the extracted tooth itself and hence there is no second surgical site. ${ }^{19}$ Powder and chip or block extracted tooth grafts with a barrier membrane are able to preserve extraction sockets with respect to height and width that was proved clinically and radiographically. Histologically, it has been proved to provide new bone formation.

The possible explanations for such results with an autogenous extracted tooth as a grafting material has been validated by various in vitro and animal studies which have demonstrated its biocompatibility, osteoinductivity, and osteoconductivity. ${ }^{18,27,28}$ A wide range of bone graft materials are available, and it is a challenging decision that will be dictated by the bone substitute material's physicochemical properties in relation to the type of defect and the main purpose of the procedure. ${ }^{24-26}$ Joshi et al., ${ }^{23}$ has shown more promising results with extracted teeth as compared to $\beta$-TCP in achieving minimum volumetric alveolar bone loss when it is grafted immediately in fresh sockets.

Minamizato et al., ${ }^{22}$ have shown acceptable outcomes of maxillary sinus augmentation with the extracted tooth grafts as well as outcomes of socket preservation for dental implant placement.

Several articles included ${ }^{19,22}$ in the systematic review mention limitations of immediate autogenous extracted tooth as a grafting material for fresh socket preservation. They include the presence of a healthy tooth root free of caries and restorations which may not be frequently present. Also, root canal treated teeth are not ideal for such a technique. It requires either buccal plate or palatal plate to present to support the graft and ensure good vascularity.

The preparation of extracted tooth graft is timeconsuming. On the other hand it is the most easily available and cost effective material. The limitations of the studies are mostly related to the study design. This systematic review included four pilot studies and one case series. Additional prospective studies are needed to validate these findings using larger sample sizes. Longer duration of evaluation will give more predictable results and would confirm its stability.

As well, such a socket preservation technique needs more comparative studies with other techniques, which employ, for example, stem cells and growth factors.

\section{CONCLUSION.}

Immediate autogenous extracted tooth as a grafting material for fresh socket preservation is promising for future daily clinical practice. Future studies are needed not only to reveal its long-term effectiveness, but to develop clinical protocols as well, that will reduce chairside graft preparation time.

Conflict of interests: The authors declare no conflict of interest.

Ethics approval: This systematic literature review adheres to the PRISMA Statement. The review protocolwas registered inan international prospective register of systematic reviews (PROSPERO ID CRD42020189487) in which the methodology and inclusion and exclusion criteria were specified and documented.

Funding: Selfunded.

Authors' contributions: All authors participated in the study design, implementation and writing of the manuscript.

Acknowledgements: None. 


\section{REFERENCES.}

1. Chappuis $\vee$, Araújo MG, Buser D. Clinical relevance of dimensional bone and soft tissue alterations post-extraction in esthetic sites. Periodontol 2000. 2017;73(1):73-83.

2. Chen ST, Buser D. Clinical and esthetic outcomes of implants placed in postextraction sites. Int J Oral Maxillofac Implants 2009: 24 (Suppl.): 186-217.

3. Ten HJ, Slot DE, Van der Weijden GA. Effect of socket preservation therapies following tooth extraction in non-molar regions in humans: a systematic review. Clin Oral Implants Res. 2011;22(8):779-88.

4. Van der, Weijden F, Dell'Acqua F, Slot DE. Alveolar bone dimensional changes of post-extraction sockets in humans: a systematic review. J Clin Periodontol. 2009; 36(12):1048-58.

5. Padial-Molina M, O'Valle F, Lanis A, Mesa F, Dohan Ehrenfest DM, Wang HL, Galindo-Moreno P. Clinical Application of Mesenchymal Stem Cells and Novel Supportive Therapies for Oral Bone Regeneration. Biomed Res Int. 2015;2015:341327.

6. Pranskunas M, Galindo-Moreno P, Padial-Molina M. Extraction Socket Preservation Using Growth Factors and Stem Cells: a Systematic Review J Oral Maxillofac Res 2019;10(3):e7

7. Camargo PM, Lekovic V, Weinlaender M, Klokkevold PR, Kenney EB, Dimitrijevic B, Nedic M, Jancovic S, Orsini M. Influence of bioactive glass on changes in alveolar process dimensions after exodontia. Oral Surg Oral Med Oral Pathol Oral Radiol Endod 2000;90:581-6.

8. Gross J. Ridge preservation using HTR synthetic bone following tooth extraction. Gen Dent 1995;43:364-7.

9. Hämmerle $\mathrm{CH}$, Chiantella GC, Karring T, Lang NP. The ef- fect of a deproteinized bovine bone mineral on bone regeneration around titanium dental implants. Clin Oral Implants Res 1998;9:151-62.

10. Iasella JM, Greenwell H, Miller RL, Hill M, Drisko C, Bohra AA, Scheetz JP. Ridge preservation with freeze-dried bone allograft and a collagen membrane compared to extraction alone for implant site development: a clinical and histologic study in humans. J Periodontol 2003;74:990-9.

11. Lekovic V, Camargo PM, Klokkevold PR, Weinlaender M, Kenney EB, Dimitrijevic B, Nedic M. Preservation of alveo- lar bone in extraction sockets using bioabsorbable mem- branes. J Periodontol 1998;69:1044-9.

12. Zizzari VL, Zara S,Tete'G,Vinci R, Gherlone E, Cataldi A. Biologic and clinical aspects of integration of different bone substitutes in oral surgery: a literature review. Oral Surg Oral Med Oral Pathol Oral Radiol Endod 2016;122:392-402.

13. Bath-Balogh M, Fehrenbach MJ. Illustrated dental embryology, histology, and anatomy. 2nd ed. Philadelphia: Elsevier; 2006.

14. Calvo-Guirado JL, Ballester-Montilla A, N De Aza P, Fernández-Domínguez M, Alexandre Gehrke S, Cegarra-Del Pino P, Mahesh L, Pelegrine AA, Aragoneses JM, Maté-Sánchez de Val J. Particulated, Extracted Human Teeth Characterization by SEM-EDX Evaluation as a Biomaterial for Socket Preservation: An in vitro Study. Materials (Basel). 2019;12(3):380.

15. Higgins JPT, Altman DG. Assessing Risk of Bias in Included Studies. Hoboken, NJ, USA: Wiley Blackwellm 2008.

16. Higgins JP, Altman DG, Gøtzsche PC, Jüni P, Moher D, Oxman AD, Savovic J, Schulz KF, Weeks L, Sterne JA; Cochrane Bias Methods Group; Cochrane Statistical Methods Group. The Cochrane Collaboration's tool for assessing risk of bias in randomised trials. BMJ. 2011;343:d5928.
17. Nasr HF, Aichelmann-Reidy ME, Yukna RA. Bone and bone substitutes. Periodontol 2000. 1999;19:74- 86.

18. Nampo T, Watahiki J, Enomoto A, Taguchi T, Ono M, Nakano H, Yamamoto G, Irie T, Tachikawa T, Maki K. A new method for alveolar bone repair using extracted teeth for the graft material. J Periodontol. 2010;81(9):1264-72.

19. Shejali J, Thomas R, Kumar T, Shah R, Mehta DS, Gayathri GV. Immediate Ridge Augmentation Using Autogenous Tooth Root as a Block Graft in a Periodontally Hopeless Extraction Site: A Pilot Study. J Oral Implantol. 2020;46(1):41-49.

20. Kim ES, Lee IK, Kang JY, Lee EY. Various autogenous fresh demineralized tooth forms for alveolar socket preservation in anterior tooth extraction sites: a series of 4 cases. Maxillofac Plast Reconstr Surg. 2015;37(1):27. Published 2015 Sep 3.

21. Canto-Díaz M, Alobera-Gracia MA, Del Canto-Pingarrón M, Martínez-González JM. Use of autologous tooth-derived graft material in the post-extraction dental socket. Pilot study. Med Oral Patol Oral Cir Bucal. 2019;24(1):e53-e60.

22. Minamizato T, Koga T, I T, Nakatani Y, Umebayashi M, Sumita Y, Ikeda T, Asahina I. Clinical application of autogenous partially demineralized dentin matrix prepared immediately after extraction for alveolar bone regeneration in implant dentistry: a pilot study. Int J Oral Maxillofac Surg. 2018;47(1):125-32.

23. Joshi CP, Dani NH, Khedkar SU. Alveolar ridge preservation using autogenous tooth graft versus beta-tricalcium phosphate alloplast: A randomized, controlled, prospective, clinical pilot study. J Indian Soc Periodontol. 2016;20(4):429-34.

24. Ramírez Fernández MP, Gehrke SA, Mazón P, CalvoGuirado JL, De Aza PN. Implant Stability of Biological Hydroxyapatites Used in Dentistry. Materials 2017, 10, 644.

25. Ramírez Fernández MP, Mazón, P.; Gehrke SA, CalvoGuirado JL, De Aza PN. Comparison of Two Xenograft Materials Used in Sinus Lift Procedures: Material Characterization and In Vivo Behavior. Materials 2017, 10, 623.

26. Ramírez Fernández, MP, Gehrke SA, Pérez Albacete Martinez C, Calvo Guirado JL, de Aza PN. SEM-EDX Study of the Degradation Process of Two Xenograft Materials Used in Sinus Lift Procedures. Materials 2017, 10, 542.

27. Jeong HR, Hwang JH, Lee JK. Effectiveness of autogenous tooth bone used as a graft material for regeneration of bone in miniature pig. J Korean Assoc Oral Maxillofac Surg. 2011;37:375-9.

28. Kim YK, Kim SG, Byeon JH, Lee HJ, Um IU, Lim SC, et al. Development of a novel bone grafting material using autogenous teeth. Oral Surg Oral Med Oral Pathol Oral Radiol Endod. 2010;109:496-503.

29. Sterne JA, Hernán MA, Reeves BC, Savović J, Berkman ND, Viswanathan M, Henry D, Altman DG, Ansari MT, Boutron I, Carpenter JR, Chan AW, Churchill R, Deeks JJ, Hróbjartsson A, Kirkham J, Jüni P, Loke YK, Pigott TD, Ramsay CR, Regidor D, Rothstein HR, Sandhu L, Santaguida PL, Schünemann HJ, Shea B, Shrier I, Tugwell P, Turner L, Valentine JC, Waddington $H$, Waters E, Wells GA, Whiting PF, Higgins JP. ROBINS-I: a tool for assessing risk of bias in non-randomised studies of interventions. BMJ. 2016;355:i4919 